\title{
Knowledge is power?
}

$\mathrm{M}$

ost of us are familiar with the adage "knowledge is power," generally attributed to English philosopher Francis Bacon. Fewer have heard the anonymous saying "Learning is like rowing upstream: advance or lose all."

Not only are today's neurologists charged with staying proficient in our fields to ensure the highest levels of patient care, we are also tasked with staying attuned to constantly changing health care models, quality assurance requirements, and legal constraints affecting our practices. This issue of Neurology ${ }^{\circledR}$ Clinical Practice provides real-world knowledge to help neurologists navigate the ever-changing practice currents.

In his article on how to work with insurance companies, Joel Kaufman (p. 448) reveals several strategies that neurologists in all practice settings can employ to facilitate communication and maximize reimbursement.

Marc Nuwer (p. 430) offers a detailed overview of chronic care management requirements and explains how neurologists can use the associated billing codes. Editorialists Satya-Murti and Busis (p. 371) explain the benefits of authorized reimbursement for non-face-to-face outpatient encounters as a means to "markedly transform management for patients with chronic neurologic conditions by improving access to timely and affordable care."

In a 3-part series on "How neurologists are paid," Donofrio et al (p. 397, p. 405, p. 412) provide specifics about the Medicaid payment system; private practice, academic, and nonclinical activities; and hospital and research roles. In their concluding statement, the authors remind us that "[r] eimbursement and compensation...should not supersede obligations to care for patients with neurologic disorders."

We welcome your feedback and personal experiences on these timely practice issues.
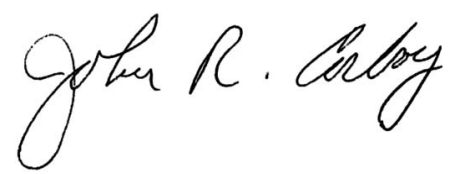

John R. Corboy, MD, FAAN

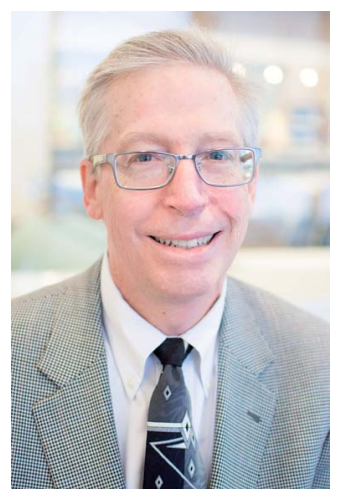




\section{Neurology ${ }^{\circ}$ Clinical Practice}

Knowledge is power?

Neurol Clin Pract 2015;5;365

DOI 10.1212/CPJ.0000000000000191

This information is current as of October 12, 2015

\section{Updated Information \&}

Services

Permissions \& Licensing

Reprints including high resolution figures, can be found at:

http://cp.neurology.org/content/5/5/365.full.html

Information about reproducing this article in parts (figures,tables) or in its entirety can be found online at:

http://cp.neurology.org/misc/about.xhtml\#permissions

Information about ordering reprints can be found online: http://cp.neurology.org/misc/addir.xhtml\#reprintsus

Neurol Clin Pract is an official journal of the American Academy of Neurology. Published continuously since 2011, it is now a bimonthly with 6 issues per year. Copyright ( $\odot 2015$ American Academy of Neurology. All rights reserved. Print ISSN: 2163-0402. Online ISSN: 2163-0933.

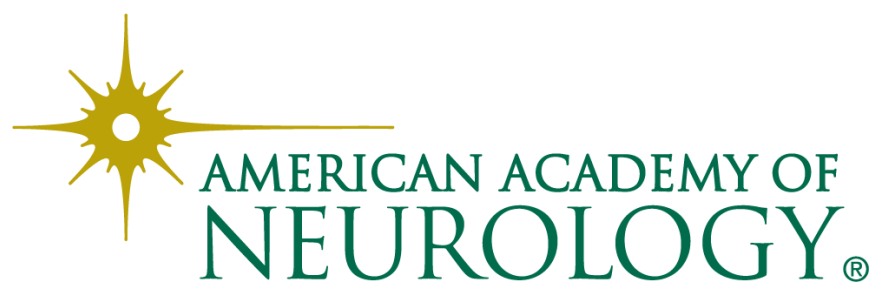

